\title{
Residues from Water Precipitation via Ferric Hydroxide Threaten Soil Fertility
}

\author{
Tomáš Brabenec ${ }^{1}\left(\mathbb{D}\right.$, Anna Maroušková ${ }^{2,3, *}$, , Tomáš Zoubek ${ }^{4}$ and Martin Filip ${ }^{4}(\mathbb{D}$ \\ 1 Department of Corporate Finance, Prague University of Economics and Business, W. Churchill Sq. 1938/4, \\ 13067 Prague, Czech Republic; tomas.brabenec@vse.cz \\ 2 Faculty of Technology, Institute of Technology and Business in České Budějovice, Okružní 517/10, \\ 37001 České Budějovice, Czech Republic \\ 3 Faculty of Economics, University of South Bohemia in České Budějovice, Studentská 13, \\ 37005 České Budějovice, Czech Republic \\ 4 Faculty of Agriculture, University of South Bohemia in České Budějovice, Studentská 1668, \\ 37005 České Budějovice, Czech Republic; zoubek@zf.jcu.cz (T.Z.); filipm07@zf.jcu.cz (M.F.) \\ * Correspondence: anna.marouskova@gmail.com; Tel.: +420-777-987-683
}

Citation: Brabenec, T.; Maroušková, A.; Zoubek, T.; Filip, M. Residues from Water Precipitation via Ferric Hydroxide Threaten Soil Fertility. Sustainability 2021, 13, 4327. https:// doi.org/10.3390/su13084327

Academic Editors: Josef Marousek, Otakar Strunecký and Marc A. Rosen

Received: 6 February 2021

Accepted: 9 April 2021

Published: 13 April 2021

Publisher's Note: MDPI stays neutral with regard to jurisdictional claims in published maps and institutional affiliations.

Copyright: (C) 2021 by the authors. Licensee MDPI, Basel, Switzerland. This article is an open access article distributed under the terms and conditions of the Creative Commons Attribution (CC BY) license (https:// creativecommons.org/licenses/by/ $4.0 /)$.

\begin{abstract}
From the moment it was first indicated that use of aluminum chloride during purification of drinking water might be one of the triggers of Alzheimer's disease, it took only a few years to almost abandon this practice worldwide. Now, two years after the initial evidence was presented that the cheapest possible replacement for aluminum chloride (ferric hydroxide, better known as ferrous sludge) significantly threatens soil fertility, there is almost no action. A robust case study was conducted among European drinking water treatment plants. First, it is reported that some samples of ferrous sludge can reduce phosphorus availability by more than $70 \%$. This creates a precondition for a significant reduction in fertility over a decade. Because the legislation usually responds to similar findings with great delay, the extent to which managers of drinking water treatment plants are willing to change process settings by themselves has also been assessed. The findings obtained allow us to expect that a long continuation of this hazardous practice can be expected, since managers of drinking water treatment plants show little willingness to switch from the ongoing questionable technology (harmful to nutrient cycles in soil) to environmentally favorable (though slightly more costly) solutions.
\end{abstract}

Keywords: food availability; water ethics; phosphorus; bioeconomy; soil fertility

\section{Introduction}

The potential questionable impacts of the preference for quick profit have already been discussed in a plethora of business ethics literature [1]. In this context, sustainability (both economic and environmental) has been adopted by many individuals and organizations as ethically responsible [2]. However, there are indications that engineers from countries in which economics lessons are required to obtain an engineering degree (instead of lessons on ethics) perceive the commitment to environmental responsibility and the implementation of environmental policies as two isolated constructs [3]. The situation is evident especially in countries that suffer from a difficult economic situation and low confidence in the country's leadership [4,5], typically in the countries of the former Soviet Union [6,7]. Consequently, more and more corporations driven by technocrats are accused of greenwashing (also referred to as eco-imagination) and misleading consumers about the environmental performance or the environmental benefits of a product or service [8]. Mardoyan and Braun [9] argue that the more dangerous the impacts of such conduct, the more advanced the cover-up methods and the more sophisticated the propaganda applied. Some of these practices are technically well hidden and their uncovering requires phenomenal and interdisciplinary expertise in the field and especially strongly developed 
(or learned, or both) ethical perception [10]. As an outcome, the growing frequency of greenwashing worldwide results in adverse reactions of customer and investor confidence in sustainable commodities and services.

According to Thales of Miletus (probably with reference to the Nile's periodic flooding), water is the arché (or the basic principle of life), and the essence of all creatures (and all forms of life) is moist [11]. Approximately $97 \%$ of the water on planet Earth is salty and some $2 \%$ of water can be found in the frozen state. Only less than $1 \%$ is freshwater but nearly half of this is groundwater [12]. To make matters worse, not all of this fraction is readily accessible to humans; only a small proportion can be considered safe according to international standards [13]. As a result, nearly one ninth of mankind lacks unlimited access to clean drinking water and it is estimated that the number of people dying each year of diseases associated with contaminated water sources is approaching the population of the USA [14]. In a growing number of cities, drinking highly treated municipal wastewater, called 'reused water', has become the best choice, and, in some situations, the last resort [15]. Freshwater stress can be addressed to a degree with drinking water treatment plants [16]. It is rational that such key points of public infrastructure belong to government or to the local community (as in the US, for example). However, many European politicians have already sold the vast majority of all public property and therefore several conglomerates are reaping impressive profits in the field [17]. Even so, the obligation remains for drinking water treatment plant operators to be engineers (five years of university degree in chemistry or chemical technology) with corresponding professional licenses, and to follow legal constraints [18]. Affordable and safe water is a competitive resource in many parts of the planet due to more intense and prolonged droughts, population growth, etc. [13]. Numerous drinking water treatment techniques (precipitation, flocculation, membrane filtration, electrochemistry, coagulation, etc.) that allow turning freshwater into drinking water can be traced in patents and the literature. Activated carbon, chitosan, graphene, clay, nanotubes and nanolayers, bentonite, metal organic frameworks, carbon dots, montmorillonites, hydrogels and nanomaterials are the most promising; however, they are up to $50 \%$ more expensive than the established technologies [19].

Drinking water treatment engineers have been using chlorination for almost nine decades [20]. However, in the 1970s it was discovered that chlorine also reacts with organic matter that is naturally present in surface waters to produce hazardous byproducts (the concern initially focused on trihalomethanes and halo-acetates). With regards to the EU [21], chlorination tends to be used nowadays only in emergencies, and even in these situations ethical reasoning is necessary to carefully weigh all the risks (carcinogenic properties of potent mutagens) and benefits (risks of microbially contaminated water). Global current practice in drinking water treatment plants prefers chemical coagulants. The cheapest in history, aluminum chloride, is currently being banned worldwide since having been identified as one of the triggers of Alzheimer's disease and senile dementia [22]. The second cheapest, ferric hydroxide is that most frequently applied by water treatment engineers worldwide [23]. Because the cost associated with the disposal of the flocculation residue of the process (the ferric sludge) is some USD 200 ton $^{-1}$ through landfill without transportation, this waste is being provided to farmers on the pretext that crops will be able to utilize the organic matter that has been coagulated from the surface water [24]. Nevertheless, a warning has recently been revealed that the application of ferric sludge into arable soil is responsible for reducing the levels of mobile $(\mathrm{Pm})$ and extractable $(\mathrm{Pe})$ phosphorus in soil [25]. In other words, there are indications that the continuation of the current practice locks the phosphorus that is already present in soil and, to make matters worse, depreciates the efficiency of future phosphorous fertilization.

Water ethics, for instance, is an extensively recognized discipline. The ethics of soil as such is also entering public awareness. Nonetheless, polemics on chemical elements such as phosphorus have always been understood in mainstream western philosophy as a techné subject, or, more precisely, an entirely technical field. With respect to established practice, ethics primarily requires human action. In this vein, subsequent polemics regarding the 
ethics of phosphorus could be interpreted as an analysis of ethical behavior in phosphorus management. It should be emphasized that phosphorus (and its biologically available forms in particular) is a fundamental nutrient for ecosystem balance and the sustainability of agricultural production. Therefore, its depletion and misuse has a direct impact on plant production and, subsequently, on animal production, with the environmental implications directly translating into significant economic and social consequences [26]. Cordell [27] and many others argue in good agreement that phosphorus scarcity and pricing represent a serious threat to global food security, while recent studies indicate that the demand for phosphorus could outstrip the finite supplies of phosphorus in the second half of the 21st century unless new and significant deposits are discovered. Morocco alone controls three quarters of the world's key source of phosphorus, phosphate rock. Morocco, China, Syria, Algeria and South Africa dominate nine tenths of the world's phosphate production. Although full-scale phosphorus recovery techniques have been shown to be technologically achievable [28], economic feasibility [6], legislation and national policies are the major reasons why these techniques are far from operational worldwide [29]. Further complicating the story, $80 \%$ of the phosphorus mined specifically for food production is lost or wasted along the supply chain due to inefficient practices.

A hypothesis is put forward as to whether European drinking water treatment engineers knowingly endanger food affordability for future generations, and if so, what countermeasures can be proposed.

\section{Methodology}

The procedure consists of four main steps. At first, randomly chosen European drinking water treatment plants are requested to provide their samples of ferrous sludge from water clarification. Secondly, ferrous sludge is analyzed, in particular in terms of interactions with soil phosphorus. Thirdly, engineers in charge of drinking water treatment plants (graduates of five-year university degree courses and holders of professional license who are responsible for plant decision-making) are provided with the latest literature which describes the chemistry by which ferrous sludge degrades the availability of phosphorus in soil for plants. Fourth, engineers are interviewed about their standpoints.

Between five and 20 drinking water treatment plants per each European country (with respect to its size) were randomly chosen via the Internet and offered ferrous sludge analysis free of charge under the condition that they send $1 \mathrm{~kg}$ of their sample in sealed polyethylene bags without any delay. Across seven European countries (Austria, Czech Republic, France, Germany, Great Britain, Italy, Switzerland) 65 samples were received within three weeks. Samples received later were not considered. All the samples were subject to biochemical analysis (levels of aluminum oxide, calcium oxide, cellulose, iron oxide, lignin, magnesium oxide, manganese oxide, oxidizable carbon, phosphorus pentoxide, silicon oxide, sulfur and volatile solids) in 10 repetitions. Subsequently, the ferrous sludge was mixed with two types of the most common European arable soil (Humic Cambisol and Gleyic Cambisol, 10 repetitions each) according to established practice (ferric-based coagulation sludge from drinking water clarification $(15 \%)$ was mixed with cattle slurry $(30 \%)$, peat $(25 \%)$, pond mud $(22 \%)$, limestone (6\%) and topsoil from farmed fields). Subsequently, the dynamics of phosphorus availability (Pm and Pe) for plant nutrition was analyzed on a monthly basis according to [25] for one year. Plant yields were analyzed via modified barley germination tests [30], and the weight change of the phytomass above ground after three months of vegetation was measured (\%).

To analyze the ethical background in the decision making of European drinking water treatment plant engineers, they were provided with (1) recent literature [31] that describes the chemistry of how ferrous sludge from drinking water clarification damages phosphorus bioavailability in soil and (2) analysis of their ferrous sludge which included the dynamics of soil phosphorus bioavailability degradation. Subsequently, engineers were asked the following questions: $\left(Q_{1}\right)$ Do you have reservations towards the use of ferric hydroxides and the subsequent use of ferric sludge for agricultural purposes?; $\left(Q_{2}\right)$ Do you have 
confidence in the results provided? $\left(\mathrm{Q}_{3}\right)$ Are the results presented by our team surprising to you?; $\left(Q_{4}\right)$ Are you willing to take any countermeasures?

\section{Results and Discussion}

Because water and phosphorus are inseparable from food production, their ethics are everyone's business [32,33]. As phosphate resources decline, phosphate fertilizers inevitably become a scarce and therefore a costly feedstock, with strict impact on agriculture and food security [34]. Access to deposits of phosphate rock is politically delicate and financially challenging [26]. Phosphorus is mandatory for the transmission of hereditary information, making it necessary for the reproduction of animals and plants. The dependency of global agriculture on imported phosphorus fertilizers and fossil fuels in particular is ambiguous [35]. To our best understanding, environmental quality and reasonably equal distribution of natural resources are not explicitly stated in any jurisdiction around the world. According to Hancock [36], the current political, ethical and legal situation needs to be redefined. His vision is that every human should have equal rights not only to a healthy environment but also to affordable natural resources. As a result, such a theory means that everybody, including the poor, i.e., society's most vulnerable group, may claim the right to affordable phosphorus. On the basis of political beliefs, some would regard such a global arrangement as a utopia and others as a dystopia [37], Nevertheless, given the global situation of the early 21st century, we can hardly imagine such a situation in the foreseeable future. The current demand for drinking water, which is becoming scarcer, is being met by drinking water treatment plants that provide their services to steeply rising numbers of people. These conglomerates do not miss an opportunity to inform their customers about the latest efforts they are making in terms of social responsibility or sustainability [17]. However, a review of the literature [19,38], in agreement with a web search and communication with water treatment plant engineers, unreservedly confirms that clarification of drinking water by ferric hydroxide is nowadays the cheapest legal and globally prevailing technology for converting fresh water into drinking water. The annual worldwide production of ferrous sludge is counted in millions of tons [24], with this amount increasing by an average rate of $5 \%$ each year, and its incorporation into arable land affects vast expanses of farmland [39].

Analyses of ferrous sludge from 65 European water treatment plants have shown negligible deviations (the accuracy of the analytical techniques used is around $1 \%$, which makes any additional statistics on deviations irrelevant) in terms of the country of origin (Table 1). This is in line with the findings of Herreño et al. [40] as well as Gomes et al., [24] who both assume that the composition of ferrous sludge from water clarification is nearly consistent all over the world.

Table 1. Biochemical characteristics of ferrous sludge (converted to volatile solids VS), where: $A=A u s t r i a ; C Z=C z e c h$ Republic; F = France; DE = Germany; GB = Great Britain; I = Italy; $\mathrm{CH}=$ Switzerland; $(\#)=$ number of water treatment plants; $\mathrm{Al}_{2} \mathrm{O}_{3}=$ aluminum oxide; $\mathrm{CaO}=$ calcium oxide; $\mathrm{Cell}=$ cellulose; $\mathrm{Fe}_{2} \mathrm{O}_{3}=$ iron oxide; $\mathrm{Lign}=$ lignin; $\mathrm{MgO}=$ magnesium oxide; $\mathrm{MnO}_{2}=$ manganese oxide; $\mathrm{C}_{\mathrm{ox}}=$ oxidizable carbon; $\mathrm{P}_{2} \mathrm{O}_{5}=$ phosphorus pentoxide; $\mathrm{SiO}_{2}=$ silicon oxide; $\mathrm{S}=$ sulfur and vs. $=$ volatile solids; $n=10 ; \alpha=0.05$.

\begin{tabular}{|c|c|c|c|c|c|c|c|}
\hline & A (13) & CZ (14) & F (9) & DE (16) & GB (3) & I (7) & $\mathrm{CH}(3)$ \\
\hline $\mathrm{Al}_{2} \mathrm{O}_{3}\left(\mathrm{mg} \cdot \mathrm{kg}^{-1}\right)$ & $0.8 \pm 0.2$ & $1.1 \pm 0.4$ & $1.0 \pm 0.5$ & $0.9 \pm 0.4$ & $1.0 \pm 0.3$ & $1.1 \pm 0.3$ & $0.9 \pm 0.2$ \\
\hline $\mathrm{CaO}\left(\mathrm{mg} \cdot \mathrm{kg}^{-1}\right)$ & $0.3 \pm 0.1$ & $0.4 \pm 0.3$ & $0.6 \pm 0.3$ & $0.3 \pm 0.2$ & $0.4 \pm 0.2$ & $0.3 \pm 0.2$ & $0.9 \pm 0.3$ \\
\hline Cell (mg.kg $\left.{ }^{-1}\right)$ & $2.0 \pm 0.4$ & $1.7 \pm 0.3$ & $2.2 \pm 0.5$ & $1.9 \pm 0.3$ & $1.9 \pm 0.6$ & $1.9 \pm 0.3$ & $2.1 \pm 0.4$ \\
\hline $\mathrm{Fe}_{2} \mathrm{O}_{3}\left(\mathrm{mg} \cdot \mathrm{kg}^{-1}\right)$ & $8.9 \pm 0.9$ & $5.3 \pm 1.2$ & $9.8 \pm 1.5$ & $8.3 \pm 3.6$ & $9.9 \pm 2.1$ & $7.0 \pm 2.4$ & $8.3 \pm 1.0$ \\
\hline Lign (mg.kg $\left.{ }^{-1}\right)$ & $1.4 \pm 0.3$ & $1.5 \pm 0.3$ & $1.5 \pm 0.6$ & $1.2 \pm 0.4$ & $1.6 \pm 0.4$ & $1.6 \pm 0.6$ & $1.5 \pm 0.2$ \\
\hline $\mathrm{MgO}\left(\mathrm{mg} \cdot \mathrm{kg}^{-1}\right)$ & $0.1 \pm 0.0$ & $0.1 \pm 0.0$ & $0.1 \pm 0.1$ & $0.1 \pm 0.0$ & $0.1 \pm 0.1$ & $0.2 \pm 0.1$ & $0.1 \pm 0.0$ \\
\hline $\mathrm{MnO}_{2}\left(\mathrm{mg} \cdot \mathrm{kg}^{-1}\right)$ & $0.1 \pm 0.1$ & $0.1 \pm 0.0$ & $0.2 \pm 0.1$ & $0.1 \pm 0.0$ & $0.2 \pm 0.1$ & $0.2 \pm 0.2$ & $0.1 \pm 0.1$ \\
\hline $\mathrm{C}_{\mathrm{ox}}\left(\mathrm{mg} \cdot \mathrm{kg}^{-1}\right)$ & $2.1 \pm 0.1$ & $2.1 \pm 0.1$ & $2.2 \pm 0.1$ & $2.1 \pm 0.1$ & $2.1 \pm 0.1$ & $2.1 \pm 0.2$ & $2.2 \pm 0.1$ \\
\hline $\mathrm{P}_{2} \mathrm{O}_{5}\left(\mathrm{mg} \cdot \mathrm{kg}^{-1}\right)$ & $0.1 \pm 0.0$ & $0.1 \pm 0.1$ & $0.1 \pm 0.0$ & $0.1 \pm 0.0$ & $0.1 \pm 0.0$ & $0.1 \pm 0.0$ & $0.0 \pm 0.0$ \\
\hline $\mathrm{SiO}_{2}\left(\mathrm{mg} \cdot \mathrm{kg}^{-1}\right)$ & $3.6 \pm 0.3$ & $3.7 \pm 0.4$ & $3.3 \pm 0.5$ & $3.4 \pm 0.5$ & $3.6 \pm 0.3$ & $3.3 \pm 0.3$ & $3.4 \pm 0.4$ \\
\hline $\mathrm{S}\left(\mathrm{mg} \cdot \mathrm{kg}^{-1}\right)$ & $0.0 \pm 0.0$ & $0.0 \pm 0.0$ & $0.1 \pm 0.0$ & $0.0 \pm 0.0$ & $0.0 \pm 0.0$ & $0.1 \pm 0.0$ & $0.0 \pm 0.0$ \\
\hline $\mathrm{VS}\left(\mathrm{mg} \cdot \mathrm{kg}^{-1}\right)$ & $21.0 \pm 3.1$ & $19.7 \pm 4.4$ & $22.5 \pm 3.5$ & $19.1 \pm 2.9$ & $16.7 \pm 3.4$ & $20.3 \pm 2.2$ & $19.5 \pm 4.4$ \\
\hline
\end{tabular}


The incorporation of samples of ferric sludge from drinking water clarification into typical European farming soils (for Humic Cambisol see Figure 1; for Gleyic Cambisol see Figure 2) according to established practice independently confirmed the reservations of Maroušek et al. [31], who pointed out the possible negative impacts on phosphorus accessibility (Pm and $\mathrm{Pe})$. Our observation is also in line with the first indications of Huang and Wang [39], who warned against "terrestrial toxicity" of ferrous sludge without addressing in detail the mechanism of its occurrence.
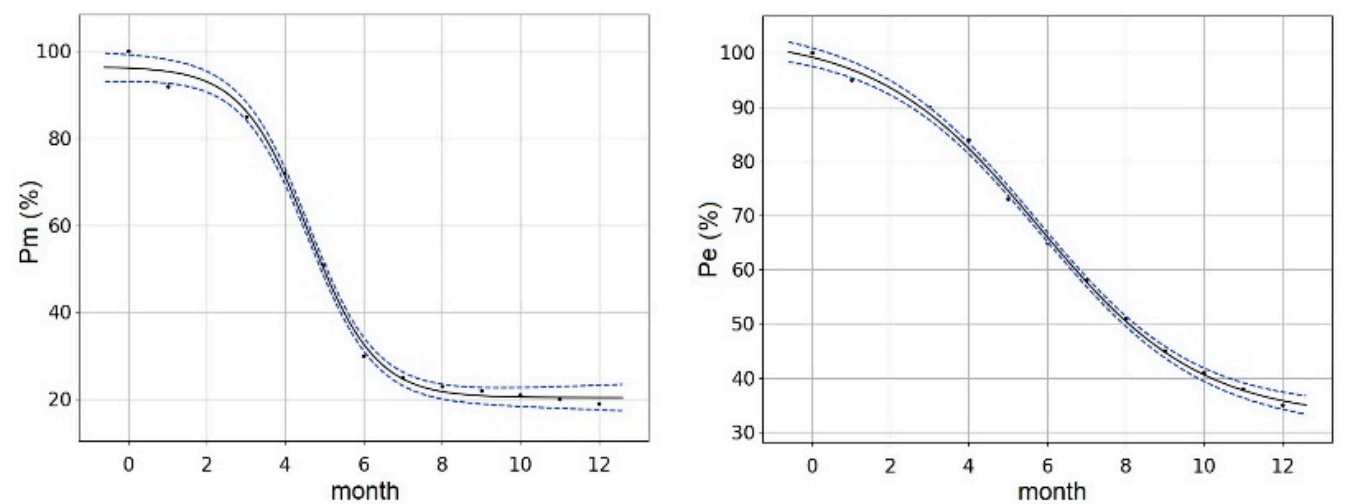

Figure 1. The decrease of phosphorus accessibility for plant nutrition after the incorporation of ferrous sludge from drinking water clarification into Humic Cambisol, where Pm = mobile phosphorus $(\%) ; \mathrm{Pe}=$ extractable phosphorus (\%) and the dashed line represents $90 \%$ confidence vicinity, $n=10$; $\alpha=0.1$.
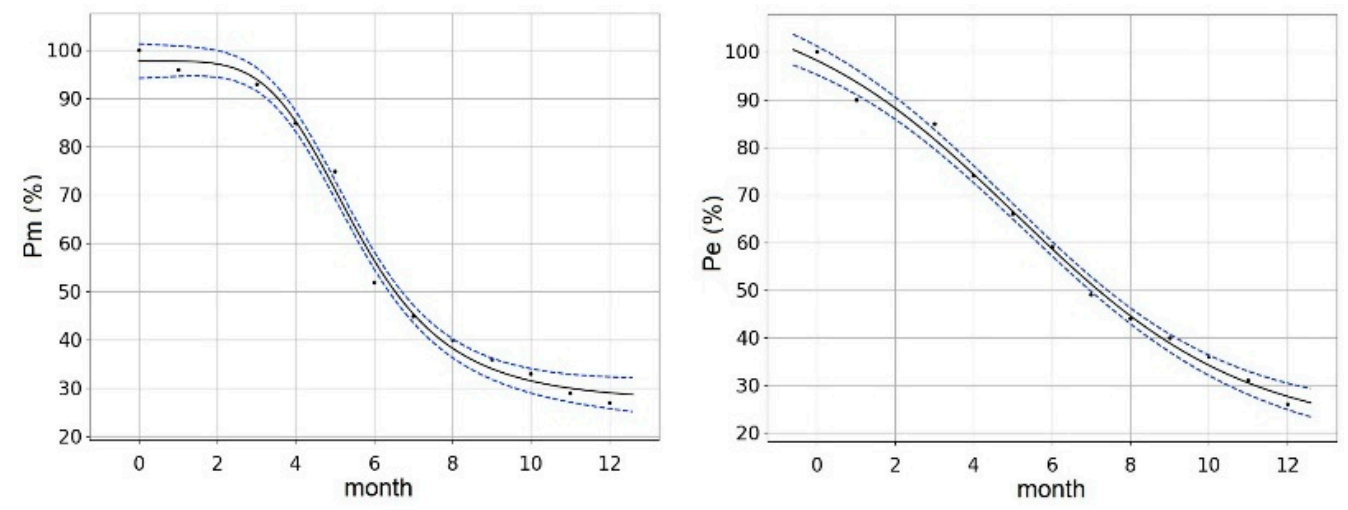

Figure 2. The decrease of phosphorus accessibility for plant nutrition after incorporation of ferrous sludge from drinking water clarification into Gleyic Cambisol, where Pm = mobile phosphorus (\%); $\mathrm{Pe}=$ extractable phosphorus $(\%)$ and the dashed line represents $90 \%$ confidence vicinity, $n=10$; $\alpha=0.1$.

As shown in Figures 1 and 2, the Pm decreases gradually in the first three months and then falls sharply to somewhere between a third to a fifth of its original levels, depending on the type of soil. The second common way to express phosphorus availability for plant nutrition, the analysis of Pe, falls almost linearly at somewhere between a third and a quarter of the original values. Following the above, it can be considered as independently proven that phosphorus accessibility for plant nutrition after the incorporation of ferrous sludge from drink water clarification into both soil types confirmed the latest indications from biochemistry literature stating that the chemical nature of the ferric sludge locks phosphorus into ferric phosphates, making it not only worthless for plant nutrition, but even harmful to nutrient cycles in soil $[23,26]$. In addition, the same mechanisms were indirectly confirmed with analyses of barley phytomass production (Table 2). 
Table 2. Analysis of decrease in barley phytomass yields (vegetation season before the experiment $=100 \%$ ) where: $\mathrm{HC}_{0}=$ Humic Cambisol; $\mathrm{HC}_{\mathrm{fs}}=$ Humic Cambisol after application of ferrous sludge from drinking water clarification; $\mathrm{GC}_{0}=$ Gleyic Cambisol; $\mathrm{GC}_{\mathrm{fs}}=$ Gleyic Cambisol after application of ferrous sludge from drinking water clarification; I-IV. vegetation season, $n=10$; $\alpha=0.05$.

\begin{tabular}{lllll}
\hline & I. & II. & III. & IV. \\
\hline $\mathrm{HC}_{0}(\%)$ & 92 & 85 & 81 & 77 \\
$\mathrm{HC}_{\mathrm{fs}}(\%)$ & 91 & 80 & 73 & 66 \\
$\mathrm{GC}_{0}(\%)$ & 96 & 94 & 92 & 91 \\
$\mathrm{GC}_{\mathrm{fs}}(\%)$ & 93 & 82 & 68 & 60 \\
\hline
\end{tabular}

Afterwards, 65 engineers in charge of the concerned drinking water treatment plants were provided with scientific literature that explains the chemistry of phosphor immobilization $[31,33]$ and with our results regarding the dynamics of Pe and Pm following the incorporation of their specific ferrous sludge (analogously as in Figures 1 and 2). All questionnaires were returned correctly filled in time, which gives us the impression of a serious response. Feedback from engineers and the main directions of their thinking are represented in Figure 3.

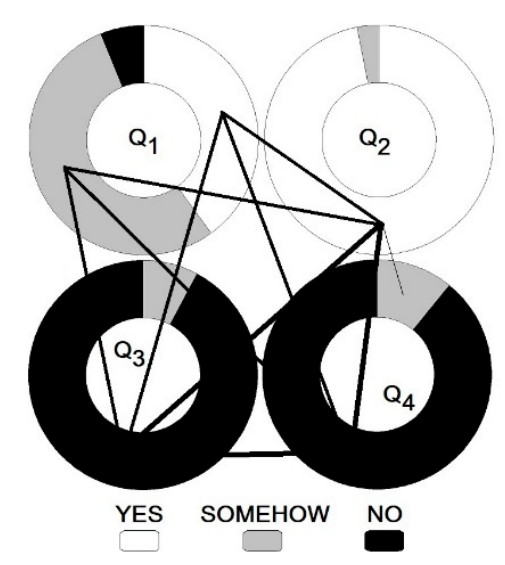

Figure 3. Visualization of the opinions of engineers responsible for water treatment plant operation (the line thickness is proportional to the number of responses), where: $\left(Q_{1}\right)$ Do you have reservations towards the use of ferric hydroxides and the subsequent use of ferric sludge for agricultural purposes?; $\left(Q_{2}\right)$ Do you have confidence in the results provided? $\left(Q_{3}\right)$ Are the results presented by our team surprising to you?; $\left(\mathrm{Q}_{4}\right)$ Are you willing to take any countermeasures?

The response to $Q_{1}$ (Do you have reservations towards the use of ferric hydroxides and the subsequent use of ferric sludge for agricultural purposes? yes $=26$; to some extent $=35$; no $=4$ ) can be interpreted as meaning that only a small number $(6 \%)$ of engineers have no reservations towards today's practices regarding ferrous sludge from drinking water clarification. In our understanding, this indicates some primary discrepancies between the engineers' inner conviction and the current state of legislation. We assume that this is due to the high level of the chemical and technical education among this specific social group, which could be associated with a high level of critical thinking. Our opinion is based on the study of Ralston and Bays [41], who reported a statistically significant increase in critical thinking over four years of higher technical education. In addition, according to Maroušek [42] European engineers are apparently educated to be skeptical towards the laws created by humans and guide themselves inherently by the laws of nature (biochemistry in this case). The origin of this controversy leads us to the debate on the current state of legislation in soil practice, which is criticized as being outdated (only the introduction of nontoxic inputs is generally considered legal, see [43]). However, there is still a long way to go from highlighting and acknowledging legal gaps to prevention. Psacharopoulos [44] 
argues that the cost of obsolete legislation is usually difficult to quantify and introduces the concept of the "social cost of an outdated law". It needs to be accepted that engineers themselves can hardly change the established legislation, but it is worth discussing whether they should at least proactively share their reservations with the public.

Regarding $\mathrm{Q}_{2}$ (Do you have confidence in the results provided? yes $=63$; to some extent $=2 ;$ no $=0$ ) it can be stated that drinking water treatment engineers perceived the argumentation in the scientific literature as conclusive and our results on phosphorus immobilization trustworthy. Of those who had reservations towards current practice in the management of ferric sludge from drinking water clarification $\left(Q_{1}\right) 100 \%$, along with $97 \%$ of those who indicated some reservations believed, in our results. It is worth noting that $75 \%$ of engineers who showed no reservations towards the current state of ferrous sludge management $\left(Q_{1}\right)$ reported confidence in the revelations by Maroušek [45] and in our analyses $\left(Q_{2}\right)$. To admit something is a prerequisite for resolving disagreements about ethical issues [46]. Numerous authors have already reported higher levels of trust in science among engineers [13]. The data obtained do not allow analysis of the extent to which the answers were linked to specific results or to research literature in general. Nevertheless, Funk [47] showed that in the USA engineers have a higher level of trust in science than an average sample of the population. Maroušek [48] stated that international analysis indicates broad similarities with engineers in Germany and the United Kingdom, including the fact that trust in research reports can fluctuate depending on who employs the authors and what the topic under discussion is.

As far as $Q_{3}$ (Are the results presented by our team surprising for you? yes = 0; to some extent $=7 ;$ no $=58$ ) is concerned, one can guess that the threat to agricultural soil is seen by water treatment engineers as of no surprise. $92 \%$ of engineers who reported confidence in the scientific literature and our work $\left(Q_{2}\right)$ were not surprised by the results. The reason is probably that our findings on phosphorus availability are in good agreement with the theoretical knowledge of iron and phosphorus biochemistry [23] and with the fact that farmers have already been complaining about the suspiciously low yields and the reported photos of crops suffering from phosphorus deficiency, even under increased phosphorus fertilization [31]. The high level of trust among engineers in general can also play a part [49].

With regard to $\mathrm{Q}_{4}$ (Are you willing to take any countermeasures? yes = 0; to some extent $=9$; no $=56$ ) it should be remembered that the engineers questioned have been carefully selected to make sure that they are responsible for the daily operation of companies and key engineering decisions. Nevertheless, the feedback of engineers on $\mathrm{Q}_{4}$ shows their lack of interest in changing the ongoing practice as well as in ethical responsibility towards environmental welfare or sustainability. Of those who were not surprised by the explanation of the iron-phosphorus chemism, either by analysis of their ferrous sludge or not, $97 \%$ are not going to make any change in their managerial practices. It is worth mentioning that all of them declare trust in the scientific literature and in our analyses. In other words, although numerous alternative technologies are known, water treatment engineers strictly follow financial indicators and exploit the obsolete status of legislation. The only advantage of such an approach that we can think of is its predictability. Alternative technologies are not illegal but are slightly more costly $[12,50]$. Building on empirical findings in agreement with the results of the questionnaire, it can be suggested that conglomerates in water management are less likely to implement environmentally friendly measures at their expense provided these have not yet been on the public radar screen to the same extent as the chemical or petrochemical industries. Ramus and Montiel [51] argue that customers often prefer to purchase goods and services from companies with a good reputation for caring about the natural environment, with the outcome that others may perceive a potential market penalty for not committing to environmental policies. Nevertheless, the water business offers the possibility to choose another supplier only in exceptional [52]. 
There is a wide consensus that the early development of humanity can be characterized as a struggle for survival [53]. Human behavioral biology gives us exact numbers of descendants and relatives for whom it is rational to sacrifice one's own life [54]. As a result of recent struggles, there are many people in developed countries who have limited concerns about their safety on a daily basis. Recently, however, phosphorus was included in the bill of twenty critical raw materials by the EU as it represents the only material that is highly relevant for agriculture and food security [26]. The limited supply on the market, the high demand from developed countries and weak currencies make phosphorus exhaustibility even more urgent for developing countries. In these regions, phosphorus scarcity is a key challenge. Following the EU subsidy policy and the trade policy of the USA, agricultural commodity prices are rising steeply in the developing world and often exceed prices in developed countries. According to Stutter et al. [55], recycled phosphorus is not likely to become a full-scale solution to a future phosphorus crisis, yet it will become a key contributor to mitigating the impact of phosphorus insufficiency. The resulting polemic engenders comments about human dignity, since there is no food or affordable life without phosphorus and those to whom it is denied are condemned to poverty or denied a living. The susceptibility to specific environmental arguments is an objective of the ethical weighting of competing beliefs and political standpoints [36]. Weighting sustainability criteria to guide engineering choices is both an ethical and a practical task (Maroušek et al., 2014). To meet the standpoints of water treatment engineers, a socially responsible solution must therefore focus on efforts to improve the overall economic performance. Huang and Wang [39] proposed turning sludge into a lightweight aggregate for civil engineering even without using any gas-releasing additives. The recent work of Herreño et al. [40] proposes using sludge as a partial substitute for clays in non-structural brick production [56]. Nevertheless, the economic aspects are still under verification. Given the pace of soil destruction, it is not advisable to delay countermeasures any further [39]. As we have already tried to point out, the social impacts are serious because phosphorus is one of the key elements necessary for the existence of life on earth and it is expected to become scarce in a few decades. Hancock [36] argues that the duties of engineers should be conceptualized in ethical terms pursuant to the reasoning of political philosophy, rather than based on legal obligations [57]. However, following the above it seems that the amended legislation could address the ethics via identification of the ongoing practice as illegal and subsequently stimulating research on ferrous sludge utilization [58]. Narrow and incomplete knowledge of corporate environmental conduct, as well as uncertainty about the regulatory punishment for greenwashing, actually contribute to greenwashing [8]. Notwithstanding this, such a project would be susceptible to the same criticisms that beset attempts to establish a philosophical basis for human rights [59]. On any occasion when engineers make use of phosphorus (regardless of whether they are water, agricultural, or other engineers in the field), they have to consider the social aspects and their commitment to future generations [60]. Only by acting in solidarity can engineers contribute to that necessary component of the common good that is peace.

\section{Conclusions}

There is a fragile harmony between mankind and nature that needs to be protected. Based on our case study, we conclude that the ethically aware conduct of engineers is a prerequisite for sustaining life during the present age. The scarcity of water and phosphorus resources is a complex challenge. It is unnecessary to increase these risks by irresponsible behavior. Our findings on the questionable behavior of water treatment engineers require urgent countermeasures. The lay public has only limited tools for recognizing greenwashing. It should be the proactive and rigorous work of academia to present the evidence and report any suspicion of unethical behavior. Nevertheless, independent researchers should not only act as a public tool or as whistleblowers. Subsequently, academia should intervene more deeply in engineers ' education and point out that, from the perspective of morality, engineers should not do certain things, even if they are financially rational, 
in terms of human life expectancy. Ethical behavior, therefore, is an obligation for every engineer; and as the above- stated case study has demonstrated, it might even be the factor that significantly conditions the survival of humanity as a whole.

Author Contributions: T.B. funding acquisition and project administration; T.Z. investigation and data curation; M.F. investigation and data curation; A.M. conceptualization, methodology, supervision and writing. All authors have read and agreed to the published version of the manuscript.

Funding: This research received no external funding.

Data Availability Statement: All data is present in the manuscript.

Conflicts of Interest: Authors declare no conflict of interest.

\section{References}

1. Kliestik, T.; Nica, E.; Musa, H.; Poliak, M.; Mihai, E.A. Networked, Smart, and Responsive Devices in Industry 4.0 Manufacturing Systems. Econ. Manag. Financ. Mark. 2020, 15, 23-29.

2. Beever, J.; Brightman, A.O. Reflexive Principlism as an Effective Approach for Developing Ethical Reasoning in Engineering. Sci. Eng. Ethics 2015, 22, 275-291. [CrossRef] [PubMed]

3. Winn, M.L.; Angell, L.C. Towards a Process Model of Corporate Greening. Organ. Stud. 2000, 21, 1119-1147. [CrossRef]

4. Maroušek, J.; Kolář, L.; Strunecký, O.; Kopecký, M.; Bartoš, P.; Maroušková, A.; Cudlínová, E.; Konvalina, P.; Šoch, M. Modified biochars present an economic challenge to phosphate management in wastewater treatment plants. J. Clean. Prod. 2020, 272, 123015. [CrossRef]

5. Maroušek, J.; Rowland, Z.; Valášková, K.; Král, P. Techno-economic assessment of potato waste management in developing economies. Clean Technol. Environ. Policy 2020, 22, 937-944. [CrossRef]

6. Kliestik, T.; Valaskova, K.; Nica, E.; Kovacova, M.; Lazaroiu, G. Advanced methods of earnings management: Monotonic trends and change-points under spotlight in the Visegrad countries. Oecon. Copernic. 2020, 11, 371-400. [CrossRef]

7. Kliestik, T.; Misankova, M.; Valaskova, K.; Svabova, L. Bankruptcy Prevention: New Effort to Reflect on Legal and Social Changes. Sci. Eng. Ethics 2017, 24, 791-803. [CrossRef]

8. Delmas, M.A.; Burbano, V.C. The Drivers of Greenwashing. Calif. Manag. Rev. 2011, 54, 64-87. [CrossRef]

9. Mardoyan, A.; Braun, P. Analysis of Czech Subsidies for Solid Biofuels. Int. J. Green Energy 2015, 12, 405-408. [CrossRef]

10. Kovacova, M.; Kliestik, T.; Valaskova, K.; Durana, P.; Juhaszova, Z. Systematic review of variables applied in bankruptcy prediction models of Visegrad group countries. Oecon. Copernic. 2019, 10, 743-772. [CrossRef]

11. O'Grady, P.F. Thales of Miletus: The Beginnings of Western Science and Philosophy; Routledge: London, UK, 2017.

12. Zaman, S.; Begum, A.; Rabbani, K.S.; Bari, L. Low cost and sustainable surface water purification methods using Moringa seeds and scallop powder followed by bio-sand filtration. Water Supply 2016, 17, 125-137. [CrossRef]

13. Singh, N.; Nagpal, G.; Agrawal, S. Rachna Water purification by using Adsorbents: A Review. Environ. Technol. Innov. 2018, 11, 187-240. [CrossRef]

14. Foster, J.E. Plasma-based water purification: Challenges and prospects for the future. Phys. Plasmas 2017, 24, 055501. [CrossRef]

15. Tortajada, C.; van Rensburg, P. Drink more recycled wastewater. Nature 2020, 577, 26-28. [CrossRef]

16. Maroušek, J.; Kwan, J.T.H. Use of pressure manifestations following the water plasma expansion for phytomass disintegration. Water Sci. Technol. 2013, 67, 1695-1700. [CrossRef] [PubMed]

17. Marasova, J.; Vallušová, A.; Vasileva, E.S.; de Saint Julien, D.P. CSR Practices: The Case of Veolia in Three European Countries. In Responsible Organizations in the Global Context; Palgrave Macmillan: Cham, Switzerland, 2019; pp. 175-197.

18. Peters, E.; Kliestik, T.; Musa, H.; Durana, P. Product decision-making information systems, real-time big data analytics, and deep learning-enabled smart process planning in sustainable industry 4.0. J. Self-Gov. Manag. Econ. 2020, 8, 16-22.

19. Bolisetty, S.; Peydayesh, M.; Mezzenga, R. Sustainable technologies for water purification from heavy metals: Review and analysis. Chem. Soc. Rev. 2019, 48, 463-487. [CrossRef]

20. Bull, R.J.; Birnbaum, L.; Cantor, K.P.; Rose, J.B.; Butterworth, B.E.; Pegram, R.; Tuomisto, J. Water Chlorination: Essential Process or Cancer Hazard? Toxicol. Sci. 1995, 28, 155-166. [CrossRef]

21. Roccaro, P.; Mancini, G.; Vagliasindi, F.G. Water intended for human consumption-Part I: Compliance with European water quality standards. Desalination 2005, 176, 1-11. [CrossRef]

22. Exley, C. Aluminum Should Now Be Considered a Primary Etiological Factor in Alzheimer's Disease. J. Alzheimer's Dis. Rep. 2017, 1, 23-25. [CrossRef] [PubMed]

23. Yin, R.; Fan, C.; Sun, J.; Shang, C. Oxidation of iron sulfide and surface-bound iron to regenerate granular ferric hydroxide for in-situ hydrogen sulfide control by persulfate, chlorine and peroxide. Chem. Eng. J. 2018, 336, 587-594. [CrossRef]

24. Gomes, S.D.C.; Zhou, J.L.; Li, W.; Long, G. Progress in manufacture and properties of construction materials incorporating water treatment sludge: A review. Resour. Conserv. Recycl. 2019, 145, 148-159. [CrossRef]

25. Maroušek, J.; Strunecký, O.; Stehel, V. Biochar farming: Defining economically perspective applications. Clean Technol. Environ. Policy 2019, 21, 1389-1395. [CrossRef] 
26. George, T.S.; Hinsinger, P.; Turner, B.L. Phosphorus in soils and plants-facing phosphorus scarcity. Plant Soil 2016, 401, 1-6. [CrossRef]

27. Cordell, D. Global phosphorus scarcity: A food secure future? J. Nutr. Intermed. Metab. 2017, 8, 61-62. [CrossRef]

28. Maroušek, J.; Stehel, V.; Vochozka, M.; Kolář, L.; Maroušková, A.; Strunecký, O.; Peterka, J.; Kopecký, M.; Shreedhar, S. Ferrous sludge from water clarification: Changes in waste management practices advisable. J. Clean. Prod. 2019, 218, 459-464. [CrossRef]

29. DeSmidt, E.; Ghyselbrecht, K.; Zhang, Y.; Pinoy, L.; Van Der Bruggen, B.; Verstraete, W.; Rabaey, K.; Meesschaert, B. Global Phosphorus Scarcity and Full-Scale P-Recovery Techniques: A Review. Crit. Rev. Environ. Sci. Technol. 2015, 45, 336-384. [CrossRef]

30. Busch, D.; Kammann, C.; Grünhage, L.; Muller, C. Simple Biotoxicity Tests for Evaluation of Carbonaceous Soil Additives: Establishment and Reproducibility of Four Test Procedures. J. Environ. Qual. 2012, 41, 1023-1032. [CrossRef] [PubMed]

31. Maroušek, J. Novel technique to enhance the disintegration effect of the pressure waves on oilseeds. Ind. Crop. Prod. 2014, 53, 1-5. [CrossRef]

32. Valaskova, K.; Throne, O.; Kral, P.; Michalkova, L. Deep learning-enabled smart process planning in cyber-physical system-based manufacturing. J. Self-Gov. Manag. Econ. 2020, 8, 121-127.

33. Stávková, J.; Maroušek, J. Novel sorbent shows promising financial results on P recovery from sludge water. Chemosphere 2021, 276, 130097. [CrossRef] [PubMed]

34. Cordell, D.; White, S. Life's bottleneck: Sustaining the world's phosphorus for a food secure future. Annu. Rev. Environ. Resour. 2014, 39, 161-188. [CrossRef]

35. Menezes-Blackburn, D.; Giles, C.D.; Darch, T.; George, T.S.; Blackwell, M.S.A.; Stutter, M.; Shand, C.; Lumsdon, D.; Cooper, P.; Wendler, R.; et al. Opportunities for mobilizing recalcitrant phosphorus from agricultural soils: A review. Plant Soil 2018, 427, 5-16. [CrossRef] [PubMed]

36. Hancock, J. Environmental Human Rights: Power, Ethics and Law; Routledge: London, UK, 2019.

37. Maroušek, J.; Myšková, K.; Žák, J. Managing Environmental Innovation: Case Study on Biorefinery Concept; Revista Técnica de la Facultad de Ingeniería Universidad del Zulia: Caracas, Venezuela, 2015; Volume 38, pp. 216-220.

38. Fan, D.; Lan, Y.; Tratnyek, P.G.; Johnson, R.L.; Filip, J.; O'Carroll, D.M.; Garcia, A.N.; Agrawal, A. Sulfidation of Iron-Based Materials: A Review of Processes and Implications for Water Treatment and Remediation. Environ. Sci. Technol. 2017, 51, 13070-13085. [CrossRef] [PubMed]

39. Huang, C.-H.; Wang, S.-Y. Application of water treatment sludge in the manufacturing of lightweight aggregate. Constr. Build. Mater. 2013, 43, 174-183. [CrossRef]

40. Herreño, L.C.F.; Solano, D.M.V.; Sarabia, K.D.R.; Pérez, J.O.C.; Quintero, A.A.M. Drinking water treatment sludge as a partial substitute for clays in non-structural brick production. J. Phys. Conf. Ser. 2019, 1409, 012013. [CrossRef]

41. Ralston, P.A.; Bays, C.L. Critical Thinking Development in Undergraduate Engineering Students from Freshman through Senior Year: A 3-Cohort Longitudinal Study. Am. J. Eng. Educ. 2015, 6, 85-98. [CrossRef]

42. Maroušek, J.; Maroušková, A.; Kůs, T. Shower cooler reduces pollutants release in production of competitive cement substitute at low cost. Energy Sources Part A Recovery Util. Environ. Effects 2020, 1-10. [CrossRef]

43. Glæsner, N.; Helming, K.; De Vries, W. Do Current European Policies Prevent Soil Threats and Support Soil Functions? Sustainability 2014, 6, 9538-9563. [CrossRef]

44. Psacharopoulos, G. The social cost of an outdated law: Article 16 of the Greek constitution. Eur. J. Law Econ. 2003, 16, 123-137. [CrossRef]

45. Maroušek, J. Study on commercial scale steam explosion of winter Brassica napus straw. Int. J. Green Energy 2013, 10, 944-951. [CrossRef]

46. Wallace, J.D. Moral Relevance and Moral Conflict; Cornell University Press: Ithaca, NY, USA, 2019.

47. Funk, C. Mixed messages about public trust in science. Issues Sci. Technol. 2017, 34, 86-88.

48. Maroušek, J. Finding the optimal parameters for the steam explosion process of hay. Revista Técnica de la Facultad de Ingeniería Universidad del Zulia 2012, 35, 170-178.

49. Muhammad, Z.; Yi, F.; Naz, A.S.; Saleem, A. An investigation of justice in supply chain trust and relationship commitment-An empirical study of Pakistan. J. Compet. 2015, 7, 71-87.

50. Zhu, R.; Chen, Q.; Zhou, Q.; Xi, Y.; Zhu, J.; He, H. Adsorbents based on montmorillonite for contaminant removal from water: A review. Appl. Clay Sci. 2016, 123, 239-258. [CrossRef]

51. Ramus, C.A.; Montiel, I. When Are Corporate Environmental Policies a Form of Greenwashing? Bus. Soc. 2005, 44, 377-414. [CrossRef]

52. Vatankhah, S.; Zarra-Nezhad, M.; Amirnejad, G. An empirical assessment of willingness to accept "low-cost" air transport services: Evidence from the Middle East. J. Tour. Serv. 2019, 10, 79-103. [CrossRef]

53. Lenhard, R.; Malcho, M.; Jandačka, J. Modelling of heat transfer in the evaporator and condenser of the working fluid in the heat pipe. Heat Transf. Eng. 2019, 40, 215-226. [CrossRef]

54. Sapolsky, R.M. Behave: The Biology of Humans at Our Best and Worst; Penguin: London, UK, 2017.

55. Stutter, M.I.; Shand, C.A.; George, T.S.; Blackwell, M.S.A.; Dixon, L.; Bol, R.; Mackay, R.L.; Richardson, A.E.; Condron, L.M.; Haygarth, P.M. Land use and soil factors affecting accumulation of phosphorus species in temperate soils. Geoderma 2015, 257-258, 29-39. [CrossRef] 
56. Jandačka, J.; Mičieta, J.; Holubčík, M.; Nosek, R. Experimental Determination of Bed Temperatures during Wood Pellet Combustion. Energy Fuels 2017, 31, 2919-2926. [CrossRef]

57. Bencsik, A.; Kosár, S.T.; Máchová, R. Corporate Culture in Service Companies that Support Knowledge Sharing. J. Tour. Serv. 2018, 9, 7-13. [CrossRef]

58. Muo, I.; Azeez, A.A. Green entrepreneurship: Literature review and agenda for future research. Int. J. Entrep. Knowl. 2019, 7, 17-29. [CrossRef]

59. Maroušek, J. Pretreatment of sunflower stalks for biogas production. Clean Technol. Environ. Policy 2013, 15, 735-740. [CrossRef]

60. Hendriks, F.; Kienhues, D.; Bromme, R. Trust in science and the science of trust. In Trust and Communication in a Digitized World; Springer: Cham, Switzerland, 2016; pp. 143-159. 